\title{
Conjugando análises para determinar a policy
}

Octavio AMORIM NETO. De Dutra a Lula: a condução e os determinantes da política externa brasileira. Rio de Janeiro, Elsevier, 2011. 200 páginas.

\section{Lucas Ribeiro Mesquita}

De Dutra a Lula pode ser considerada uma das primeiras obras do gênero no país, ao fundir análises quantitativas com análises qualitativas na descrição dos determinantes da política externa brasileira entre 1946 e 2008. Pela utilização do modelo longitudinal, no qual a política externa brasileira é a variável dependente, o autor explica e quantifica em uma ótica multicausal a influência dos fatores sistêmicos e domésticos no processo decisório da política externa brasileira.

A intenção de Amorim parece se aproximar das preocupaçôes de alguns autores de política externa brasileira. De acordo com Sanchez-Badin e França (2010), apesar das mudanças institucionais ainda pendentes, permanece a pergunta sobre como no dia a dia o Estado brasileiro e seus diferentes órgãos de atuação internacional articulam-se com o MRE, entre si e com a sociedade civil. Para Cervo (2008), ainda é perceptível a necessidade de pesquisas que analisem a relação entre governos, partidos e ideologias e suas influências na política externa brasileira contemporânea, aproximando a conceituação de política externa como outra política pública. Com efeito, o grande trunfo de Amorim Neto está em aferir o peso das variáveis domésticas e sistêmicas no processo decisório da política externa, utilizando como parâmetro a análise quantitativa das votações brasileiras e dos Estados Unidos na Assembleia Geral da ONU entre 1946-2008.

Paradoxalmente seu parâmetro é a sua principal fraqueza. Ao tentar mensurar os determinantes somente pela análise dos votos na Assembleia Geral, o autor superestima seu peso nas decisóes internacionais, marginalizando outros espaços multilaterais de atuação e proposição, os quais hoje, em função de uma ordem internacional possivelmente multilateral, são importantes lócus de formatação e negociação política.

Apesar da histórica e "democrática" importân- 
cia da Assembleia Geral das Nações Unidas, não há sempre convergência de posicionamento por parte dos Estados. O Estado, ao atuar em uma questão, pode englobar em seu cálculo determinantes de outras instâncias do tabuleiro internacional. Supõe-se que a atuação de um país, ou melhor, os fatores que determinam sua política externa, pode variar em função do local, ou representar apenas uma pequena parte do cálculo.

Outro ponto problemático do livro é a amplitude do recorte temporal, uma vez que o modelo pode ser enfraquecido em virtude de mudanças recentes da política externa brasileira. Mesmo que não tenha ocorrido transformações bruscas e definitivas nos padrôes e nas regras institucionais do país, é consenso na literatura a afirmação de que a política externa brasileira vivencia uma mudança no processo decisório.

Quando se buscam padrões de afirmação na política externa brasileira, primeiramente vem à tona o protagonismo do Itamaraty no policy making. Como sugerem Hirst e Lima (2002), embora esse modelo possa explicar o processo decisório de política externa de grande parte do século $\mathrm{XX}$, ele já não se mostra tão eficaz, pois fatores internacionais, domésticos e mesmo de corte epistemológico incidiram sobre a própria natureza da política externa. Nesse sentido, talvez fosse mais proveitoso analisar a política externa a partir do conceito de ciclos políticos, pois é fundamental não perder de vista o processo histórico que envolveu a elaboração e a implementação das políticas. Ainda que tal abordagem seja muito recente (Belém Lopes, Santos e Faria, 2012), ela supera as dificuldades e as inconsistências das molduras analíticas behavioristas de foreign policy analysis. Além de conferir densidade e profundidade às análises por não negligenciar a sociologia política, a operação de fusão entre técnicas da Análise de Política Externa e da análise convencional de políticas públicas assegura comparaçôes significativas entre os objetos em tela (Idem).

Afora essas questões, o livro inicia um novo marco dos estudos da política externa brasileira. Oriunda de uma escola francesa, na qual a história sempre serviu de guia metodológico, a política externa brasileira tem, para usar uma expressão corrente na área da ciência política nacional, como calcanhar de Aquiles a utilização de técnicas qualitativas em detrimento de técnicas quantitativas ou a junção de ambas. O livro rompe com esse dogma, elevando a política externa a novos patamares.

$\mathrm{Na}$ primeira parte do livro, Amorim Neto apresenta seu projeto de pesquisa, cuja introdução se dedica à defesa da necessidade, e a plausibilidade, de estabelecer indicadores operacionalizáveis para analisar a política externa. Em seguida, o autor determina, a partir de uma discussão teórica, as variáveis que serão incorporadas em seu modelo.

A ênfase é dada tanto às teorias realistas e liberais, sob as quais o autor constrói as variáveis sistêmicas do modelo - respectivamente "capacidade relacional do Estado brasileiro" e "dependência econômica em relação aos Estados Unidos" -, como aos trabalhos sobre tomada de decisão em política externa, nos quais busca a justificativa relacional entre política interna e política externa, e posteriormente aos trabalhos que avaliam as instituições domésticas e sua capacidade de influência decisória.

$\mathrm{O}$ autor trabalha em torno da avaliação dos regimes políticos, das legislaturas e dos sistemas e tipos de governo. Posteriormente, o foco incide sobre a literatura clássica da política externa brasileira Cervo, Gelson Fonseca, Maria Regina Soares de Lima, Letícia Pinheiro, Hirst -, para lançar as expectativas, confirmadas pelos dados quantitativos, sobre a convergência entre Brasil e Estados Unidos nas votaçôes.

$\mathrm{Na}$ segunda parte, Amorim Neto apresenta os atores e as estruturas institucionais que compóem o processo decisório. Há muitos questionamentos que perpassam a construção desses indicadores, daí a importância em mapeá-los. O autor questiona o peso da ideologia presidencial, a questão do apoio legislativo e a composição dos gabinetes como fatores capazes de influenciar a política externa. Concomitantemente, é discutido o papel do Congresso e dos partidos políticos na determinação política, verificando a relação entre as mudanças na configuração legislativa ou o peso da esquerda partidária nas decisões.

Em seguida, as preocupações do autor se voltam para o papel político da burocracia diplomática e militar, na tentativa de avaliar se as variações 
na burocracia são fatores que influenciam o padrão de votação. Para operacionalizar os indicadores, Amorim analisa as viagens presidenciais, a nomeação de ministros e a manutenção da elite diplomática, discutindo a tênue relação entre autonomia decisória, participação direta do presidente na execução da política externa e o papel dos ministros militares.

A última parte apresenta as conclusões da pesquisa. Quando a análise abrange a totalidade das votações, os resultados tendem à reafirmação do papel da burocracia e da influência mitigada da esquerda nacional, porém evidenciam o maior peso da variável sistêmica realista em relação a fatores domésticos. Quanto a questões de segurança e política, os resultados, por sua vez, revelam que os fatores domésticos têm maior peso na dinâmica da produção política, como, por exemplo, a composição ideológica ministerial. As outras variáveis não apresentam peso considerável na decisão. Mesmo que a variável realista tenha sobressaído na análise dos dados, o autor mostra-se sensível à relevância de fatores domésticos, como a influência ideológica e do Itamaraty, fato que reflete a complexidade da área de produção da política externa e eleva a discussão a patamares de maior rigor científico.

Conforme Devin e Toernquist-Chesnier (2010), há um movimento global de proliferação de atores envolvidos em assuntos internacionais, com a consequente fragmentação do monopólio diplomático, transformando a maneira de se fazer diplomacia e política externa. Entretanto, no Brasil, a maioria dos estudos acadêmicos nesta área, apesar dos avanços, restringe a pesquisa à interação de somente um ator ou variável, a despeito do entendimento holístico da complexidade que envolve as questôes de política externa.

Em suma, é evidente a necessidade de novas ferramentas analíticas para compreender a crescente gama interacional entre os diversos interesses $\mathrm{da}$ nova política externa brasileira, o que denota a relevância desta obra, embora o próprio autor reconheça que suas conclusões e mesmo o modelo adotado sejam datados, necessitando de revisão pelo fato de não comportarem as mudanças recentes no processo decisório da política externa brasileira.

\section{BIBLIOGRAFIA}

BELÉM LOPES, Dawisson; SANTOS, Manoel \& FARIA, Carlos Aurélio Pimenta de. (2012), "Ciclos de produção da política exterior nas democracias da América Latina: uma proposta de investigação para além do behaviorismo comparativista e das teorias sistêmicas das relaçōes internacionais". Trabalho apresentado no 360 Encontro Anual da Associação Nacional de Pós-graduação em Ciências Sociais. Águas de Lindoia, SP.

CERVO, Amado. (2008), Inserção internacional: formação dos conceitos brasileiros. São Paulo, Saraiva.

DEVIN, Giullaurne \& TOERNQUIST-CHESNIER, Marie. (2010), "Burst diplomacy - the diplomacies of foreign policy: actors and methods". Brazilian Political Science Review, 4: 60-77

HIRST, Mônica \& LIMA, Maria Regina. (2002), "Contexto internacional, democracia e política externa”. Política Externa, 11 (2): 78-90.

SANCHEZ-BADIN, M. \& FRANÇA, C. (2010), $A$ inserção internacional do poder Executivo federal brasileiro. São Paulo, Friedrich-Ebert-Stiftung.

LUCAS RIBEIRO MESQUITA é professor de Relaçóes Internacionais na Faculdade Anglo-Americano/UDC, doutorando em ciência política na UFMG, mestre em ciência política na Unicamp e bacharel em Relaçóes Internacionais na PUC Minas. E-mail: <lucaskazao@gmail.com>. 